\title{
BIOLOGICAL NUTRIENT REMOVAL EFFICIENCIES FOR HYDRAULICALLY OVERLOADED WASTEWATER WORKS
}

\author{
THANDEKA Y. S. JWARA, PAUL MUSONGE, BABATUNDE F. BAKARE \& MLULEKI MNGUNI \\ Scientific Services Division, Umgeni Water, South Africa
}

\begin{abstract}
In this current age the environmental laws have become more stringent towards health, economy and reduction of pollution at the point of sources. Results of a comprehensive study are reported for Darvill wastewater works (WWW) inflow in relation to biological nutrient removal process. The incoming and outgoing nutrient (ammonia and soluble reactive phosphorus (SRP)) concentrations were determined using standard testing methods. Calculations of biological nutrient removal (BNR) efficiencies were used to evaluate the effects of high inflow to the biological treatability of the activated sludge for the period 2016-2017. At inflows above design capacity the nutrient removal efficiency was found to be at an average of $40 \%$ and SRP removal efficiency being $64 \%$ for the period of the study. The nutrient removal efficiency had an inversely proportional relationship to the inflow into the plant with ammonia removal being mostly affected. When the plant is overloaded the BNR process is adversely affected. Keywords: biological nutrient removal, hydraulically overloaded plants, nutrient removal efficiency.
\end{abstract}

\section{INTRODUCTION}

Wastewater treatment is a critical chain in the urban water cycle. Nature has its own means of attenuating waste however in larger volumes and concentrations the process becomes slower and more problematic. This has led to the design of wastewater works (WWW) which are intended to aid in the faster biodegradation and removal of pollutants found in waste water [1]. The purpose of a WWW can be elaborated as the treatment of municipal and industrial wastewater (WW) to acceptable effluent quality, devoid of excess organics chemical oxygen demand (COD), ammonia $\left(\mathrm{NH}_{3}\right)$, and nitrogen $(\mathrm{N})$ and phosphorus $(\mathrm{P})$ nutrients.

When these nutrients are released into a water resource they cause an unnatural stimulation of organisms such as algae and certain aquatic vegetation such as water hyacinths. This in turn can affect the suitability of water for farming, recreation or potable (drinking) use. It is for this reason that much attention has been given lately to biological nutrient removal (BNR)+ [2]. A new deal for wastewater engineers is now to stretch the performance of existing infrastructure, which represents one of the most significant challenges to the practice of wastewater engineering [3]. Traditionally, the complexity associated with implementing BNR in WWW has been primarily in terms of balancing competing requirements for nitrogen and phosphorus removal, particularly with respect to the use of influent COD as a carbon source for the microorganisms [4].

The nitrogen that enters the wastewater system is found as $\mathrm{NH}_{3}$, ammonium ions $\left(\mathrm{NH}^{4+}\right)$, nitrites $\left(\mathrm{NO}^{2-}\right)$ and nitrates $\left(\mathrm{NO}^{3-}\right)$ in wastewater. Ammonia and ammonium ions are the most reduced forms of nitrogen and are often products of organic decomposition. Nitrite is, however, the intermediate, with nitrate being the end product of organic oxidation during nitrification [5]. Ammonia and Ammonium ions are both commonly referred to as "ammonia nitrogen". This form of ammonia will be observed in this study. Nitrification is mediated by specific chemical autotrophic nitrifying bacteria (Fig. 1). Henze et al. [6] infer that these bacteria obtain their carbon requirement (anabolism) from dissolved carbon dioxide $\left(\mathrm{CO}_{2}\right)$ 


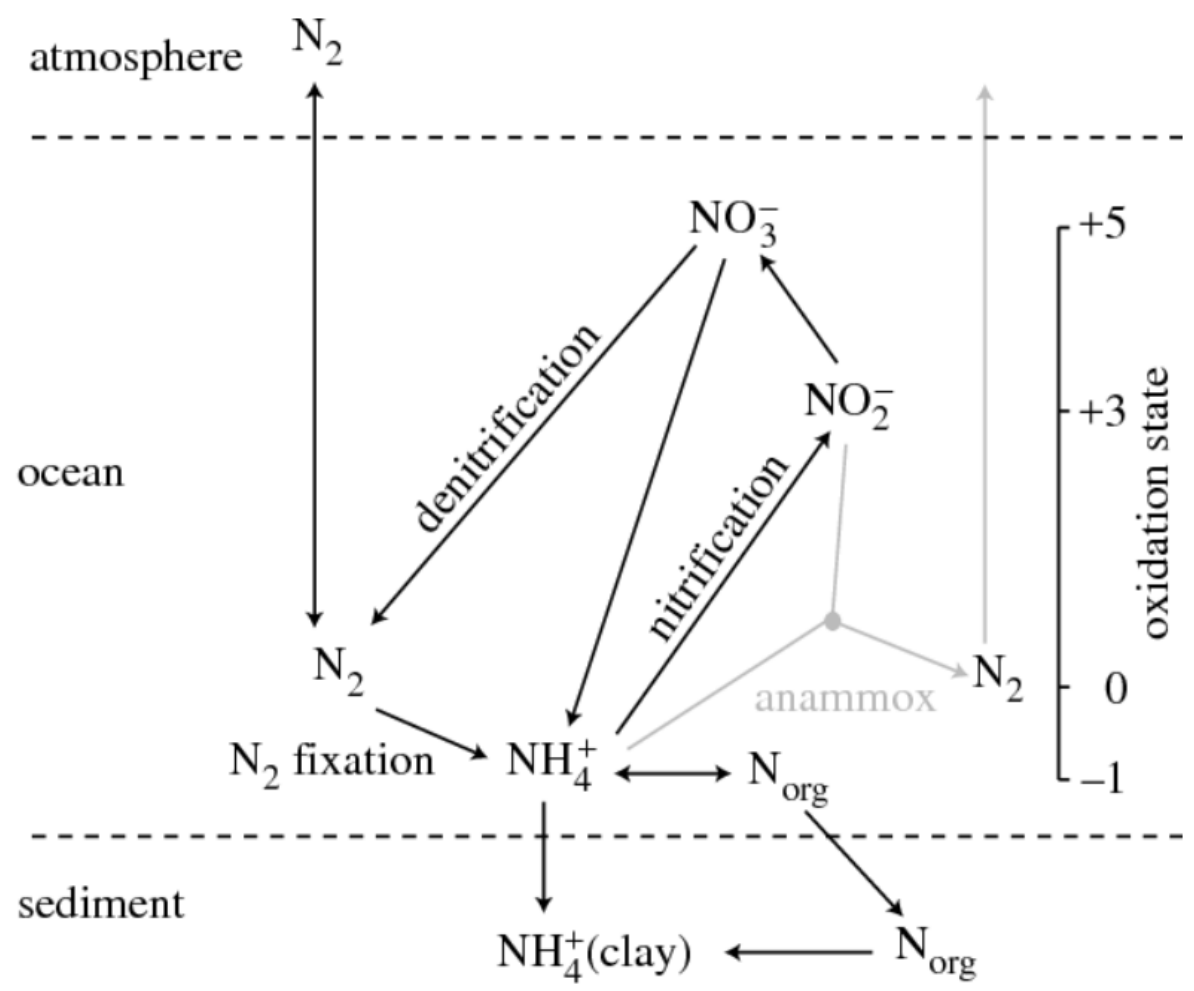

Figure 1: Nitrogen cycle depicting the nitrification and denitrification process [9].

and their energy requirement (catabolism) for biomass synthesis from oxidizing the ammonia nitrogen to nitrite and nitrate. The autotrophic nitrifying bacteria have much lower growth coefficients (1/5th) as compared to the heterotrophic bacteria which are also present in the activated sludge reactor for organic waste breakdown. Industrial effluent has a high concentration of nitrogen and a low $\mathrm{C} / \mathrm{N}$ ratio. The main problems in maintaining high nitrification efficiency when treating low $\mathrm{C} / \mathrm{N}$ wastewaters are changes in influent concentration and flow, which may also affect the dissolved oxygen level in the reactor, and $\mathrm{pH}$ due to fluctuating industrial operations [7]. The activated sludge process is the most commonly used technology for biological wastewater treatment [8].

Domestic wastewater is also relatively rich in phosphorus compounds. Wentzel et al. [10] suggested that the removal of this phosphorus in wastewater is achieved by encouraging the accumulation of $\mathrm{P}$ in the microbial cells in the form of polyphosphate (polyP) granules in excess of the levels normally required to satisfy the metabolic demand for growth. This storage process is commonly referred to as "enhanced biological phosphorus removal" (EBPR). This $\mathrm{P}$ uptake and polyP storage is done by organisms known as polyP accumulating organisms (PAO). Curtin et al. [11] reported that the PAOs under anaerobic conditions convert organic material into energy rich carbon compounds called Polyhydroxyalknoates (PHAs). Energy required for this process is generated through the breakdown of polyP which results in increase of $\mathrm{P}$ concentration in the anaerobic zone (Fig. 2). When the cells are removed from the process during sludge wasting then so is the P [12]. Under aerobic conditions energy is restored through P uptake [11]. 


\section{Anaerobic}

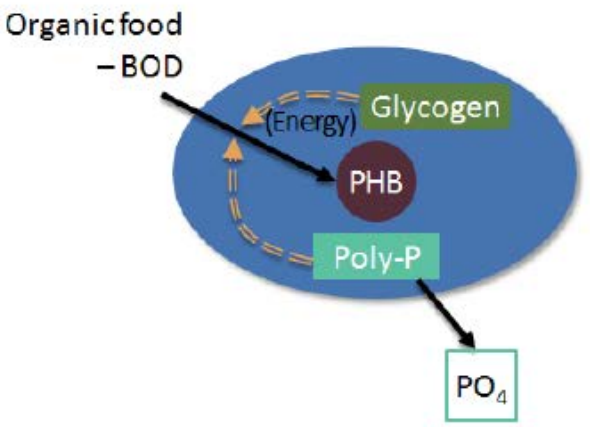

\section{Aerobic}

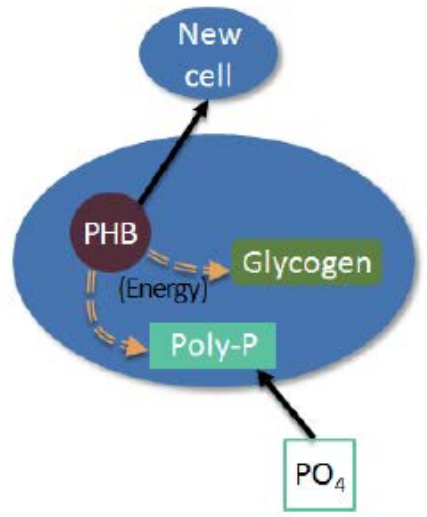

Figure 2: Mechanism of biological Phosphorus removal [11].

The consequences of contamination are the loss of aquatic life, upsurge of eutrophication, and potential loss of human life due to waterborne diseases [13]. Hence Rajasulochana and Preethy [13] attest that it has become an essential need for today's environment to protect water from getting polluted or to develop cost effective remedial methods for its protection to ensure that the water resources are maintained for future generations.

The operation of a WWW is subject to comply with the national legislative requirements of the Department of Water and Sanitation (DWS) in order to protect the water resources the WWW discharges into. Darvill WWW was used for this study. The plant is operated on the basic design of the conventional activated sludge configuration which consists of primary settling tanks (PST), activated sludge reactor and secondary settling tanks (SST). Darvill WWW discharges into the Umsunduzi River. The Darvill WWW discharge limits for $\mathrm{NH}_{3}$ and SRP are $6 \mathrm{mg} \mathrm{N} / 1$ and $1 \mathrm{mg} \mathrm{P} / 1$, respectively. It is situated in Pietermaritzburg owned by Umgeni Water. It has an average dry weather flow (ADWF) design capacity of $65 \mathrm{Ml} / \mathrm{d}$; however, the WWW has been receiving wastewater inflow as high as $120 \mathrm{Ml} / \mathrm{d}$ for the period of 2016-2017. Darvill WWW has had a challenge with nutrient removal through this period and its legal compliance had decreased. The study seeks to evaluate the effects of the high inflows on the BNR process. The nutrients to be studied are ammonia and SRP.

As far as wastewater treatability is concerned Zhirong et al. [4] attest that conventional BNR activated sludge systems, such as the Johannesburg process, the University of Cape Town (UCT) process, and the Virginia Initiative Plant process, have been implemented with considerable success throughout the world as an effective means to remove, down to low levels, both nitrogen and phosphorus without, in many cases, the need for chemical dosing (ferric, alum, methanol, etc.) A nutrient removal efficiency study conducted by Adonadaga [8] compared influent and effluent values to determine the removal efficiency of various plants. He found that certain plants gave higher $\mathrm{NH}_{3}$ removal efficiency $(75 \%)$ for industrial wastewater than municipal wastewater $(25 \%)$ The differences in removal efficiencies obtained by this study compared to results by other authors who reported efficiencies between $68 \%$ and $80 \%$ were suspected to be a result of differences in characteristics of the wastewater. Domestic wastewater is subject to wide variations in flow and load resulting in wide variations of influent nutrient ratios. 


\section{MATERIALS AND METHODS}

\subsection{Wastewater works}

Darvill wastewater works is used to conduct this study. The main focus area is the performance of the activated sludge reactor when subjected to flows above its design capacity of $65 \mathrm{Ml} / \mathrm{d}$.

\subsection{Sampling}

A 1 litre representative grab sample of settled sewage and final effluent to the river was collected and appropriately labelled every morning at 8:00 am at Darvill WWW. Settled sewage is the supernatant sludge from the primary settling tank that goes into the activated sludge reactor. The collection times and sampling points were kept constant throughout the time of the study. Once samples were collected they were stored in a cooler box with ice and transported immediately to the laboratory where they were handled within three days after drop-off.

\subsection{Laboratory analysis}

The concentrations of ammonia and SRP were determined as outlined by the Standard Methods (1995) for ammonia and SRP determination. Briefly, the samples were centrifuged at $5000 \mathrm{rpm}$ for 5 minutes (Megafuge $3.0 \mathrm{R}$ ) and the clear supernatants analyzed accordingly. The instrument used to determine the concentration of $\mathrm{NH}_{3}$ and SRP was the DR900 Spectrophotometer.

\subsection{Statistical analysis and calculations}

The concentrations from the lab analyses were used to calculate the BNR efficiency of each parameter in the settled sewage and final effluent sample (eqn (1)). The plant inflow was recorded hourly and an average for the day was recorded

$$
\text { Removal Efficiencies }=\frac{(\text { Settled sewage concentration-Final effluent concentarion })}{(\text { Settled sewage concentration })} .
$$

Microsoft Excel, was used to plot the scatter plots for comparing the BNR efficiencies to the plant inflow.

\section{RESULTS AND DISCUSSION}

The plant flows for 2016-2017 were plotted and compared to the removal efficiencies of ammonia and SRP. This was done to establish the effects of hydraulic overloading on the BNR process of Darvill WWW.

The trend on the graph (Fig. 3) suggests that the removal efficiency of $\mathrm{NH}_{3}$ has a predominantly inversely proportional relationship to the plant inflows. The average removal efficiency of ammonia during the period of 2016 and 2017 was $42 \%$ and $38 \%$, respectively. Darvill WWW has a design capacity of $65 \mathrm{Ml} / \mathrm{d}$, however it can be seen that there have been numerous periods where the plant was operating above capacity, with peaks as high as $120 \mathrm{Ml} / \mathrm{d}$. November 2016 on average had the highest inflows $(88 \mathrm{Ml} / \mathrm{d})$ however the lowest removal efficiency was seen in June 2017 (23.2\%) with a flow of $48.9 \mathrm{Ml} / \mathrm{d}$. This was due to procurement delays of faulty subsurface aerators which resulted in process upsets. This could also be related to the cold Pietermaritzburg winter temperatures which could reach a 


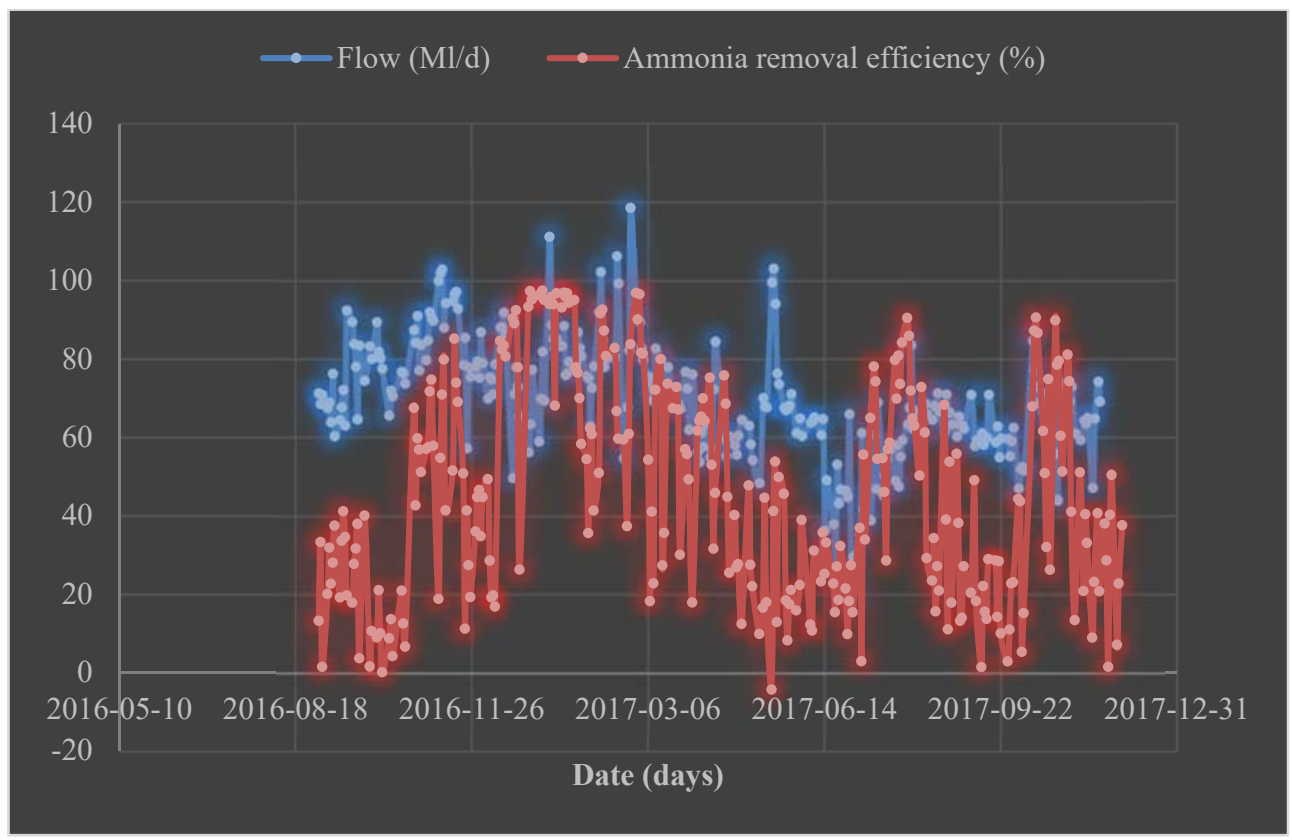

Figure 3: Ammonia removal efficiency and Darvill WWW inflow comparison.

minimum of $5^{\circ} \mathrm{C}$. Previous studies indicated that denitrification rate was significantly affected by lower temperatures for biological treatments and denitrification rate at $5^{\circ} \mathrm{C}$ was decreased by 10 times linearly as compared to that at $20^{\circ} \mathrm{C}$ [15]-[17]. The temperature effects on BNR are primarily related to the low growth rate of the nitrifying bacteria at low temperatures [14]. Ydstebo et al. [18] however found that Nitrogen removal at low temperatures was achieved by operating at a high mixed liquor suspended solids (MLSS) concentration of 6000-8000 mg/l and with a sufficient supply of organic matter for denitrification. This however could not be observed for Darvill WWW as this concentration of MLSS led to other process challenges, i.e. sludge bulking. Wastewater treatability depends largely on the characteristics of the sewage and the activated sludge conditions [6]. A higher inflow comes with higher organic and nutrient loads hence compromising the BNR process. It was seen that for the most part of the months of the study the ammonia removal efficiency was below 75\% (Table 1); this shows that the Darvill WWW treatment process was strained.

The average removal efficiency of SRP during the period of 2016 and 2017 was $61 \%$ and $67 \%$ for the two years respectively. The trend shows a predominantly inversely proportional relationship (Fig. 4). The results from this study suggest that higher flows have a higher detrimental effect on the removal efficiency of ammonia than SRP. This is largely due to the fact that ammonia is removed during the nitrification process in the activated sludge reactor. The amount of dissolved oxygen available in the system becomes inadequate and the growth of the autotrophic nitrifying bacteria is compromised when the plant receives flows above capacity. At flows above design capacity there is also a significant increase in organic loading which also requires and competes for the available dissolved oxygen in the activated sludge 
Table 1: Average monthly inflow and ammonia removal efficiency values.

\begin{tabular}{|c|c|c|}
\hline Month/Year & Flow average & Removal efficiency average \\
\hline Sep-16 & 73.7 & 24.1 \\
\hline Oct-16 & 79.3 & 27.6 \\
\hline Nov-16 & 88 & 51.9 \\
\hline Dec-16 & 75 & 63 \\
\hline Jan-17 & 81.1 & 87 \\
\hline Feb-17 & 84.5 & 68.9 \\
\hline Mar-17 & 74.7 & 55.1 \\
\hline Apr-17 & 60.9 & 50.2 \\
\hline May-17 & 70.8 & 25.7 \\
\hline Jun-17 & 48.9 & 23.2 \\
\hline Jul-17 & 52.2 & 59.2 \\
\hline Aug-17 & 66.4 & 42.3 \\
\hline Sep-17 & 60.8 & 19.8 \\
\hline Oct-17 & 64.9 & 60 \\
\hline Nov-17 & 64.2 & 29 \\
\hline
\end{tabular}

reactor. The PAOs are able to compete successfully with other organisms for substrate in completely aerobic activated sludge systems [10]. The removal efficiency of SRP is mostly affected by the hydraulic overloading as some of the PAOs get washed out with the final effluent.

Reddy et al. [19] also found reduced SRP removal at low temperatures which is related to reduced biological reaction rates however Darvill WWW SRP removal efficiency was not significantly adversely affected by temperature. In addition, it has been found that the monitoring and regulation of online parameters such as $\mathrm{pH}$, DO, ORP and nutrient pollutants (phosphorus and $\mathrm{NH}^{4+}-\mathrm{N} / \mathrm{NO}^{2-}-\mathrm{N} / \mathrm{NO}^{3-}-\mathrm{N}$ ) can be helpful in achieving and maintaining high nutrient removal for treating real municipal wastewater [20]. Therefore, any process upsets can also affect the performance of the microorganisms in the activated sludge reactor.

The average monthly data (Table 2) shows that the highest removal of SRP (80.8\%) was achieved in June 2017 at a flow low flow of $49 \mathrm{Ml} / \mathrm{d}$. This shows that the process upset during this time had little to no effect on the PAOs ability to uptake the phosphorus in the system. This is mostly due to the fact that PAOs are facultative microorganisms which means they can survive in the presence and absence of oxygen. 


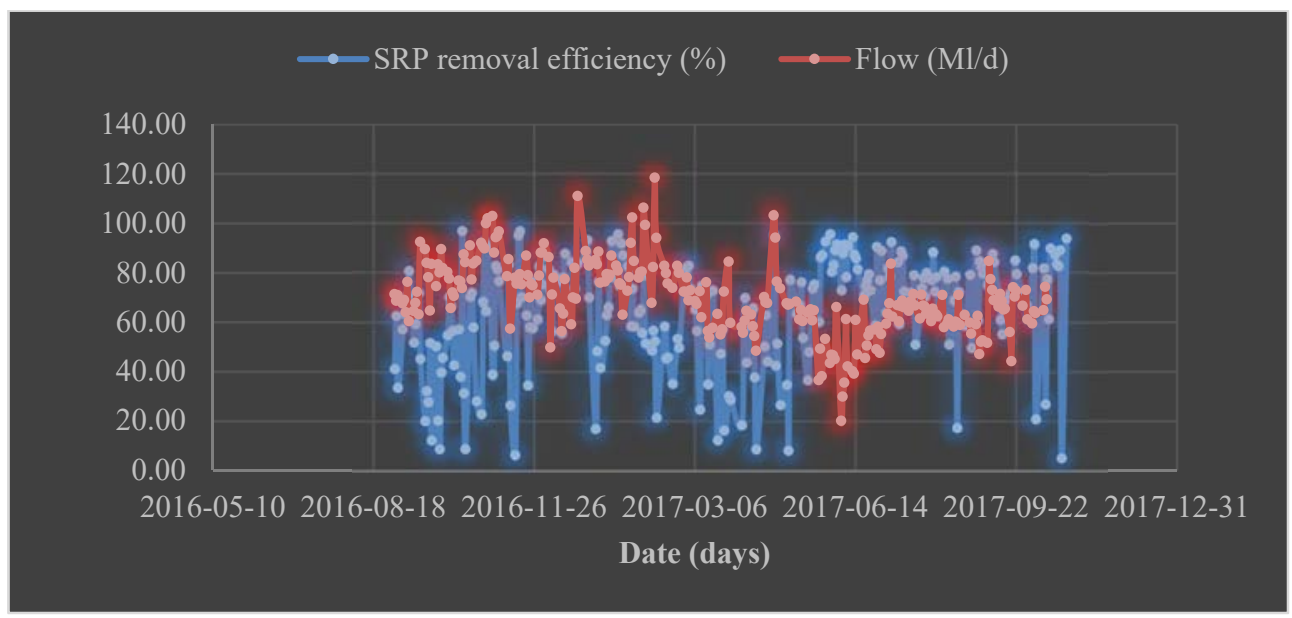

Figure 4: SRP removal efficiency and Darvill inflow comparison.

Table 2: Average monthly inflow and SRP removal efficiencies values.

\begin{tabular}{|c|c|c|}
\hline Month/Year & Inflow average (MI/d) & Removal efficiency average (\%) \\
\hline Sep-16 & 74.7 & 47.4 \\
\hline Oct-16 & 84.0 & 56.6 \\
\hline Nov-16 & 80.3 & 64.4 \\
\hline Dec-17 & 76.5 & 77.8 \\
\hline Jan-17 & 80.9 & 69.0 \\
\hline Feb-17 & 84.6 & 54.3 \\
\hline Mar-17 & 66.3 & 52.0 \\
\hline Apr-17 & 67.8 & 49.1 \\
\hline May-17 & 57.3 & 66.6 \\
\hline Jun-17 & 49.0 & 80.8 \\
\hline Jul-17 & 66.3 & 74.0 \\
\hline Aug-17 & 60.5 & 69.1 \\
\hline Sep-17 & 66.5 & 73.0 \\
\hline Oct-17 & 69.3 & 70.6 \\
\hline
\end{tabular}

\section{CONCLUSION}

The study was aimed at understanding the effects of inflows to the biological nutrient removal process of Darvill WWW. The findings suggest that a plant operating above capacity becomes compromised in its ability to biologically treat the nutrients that come with the wastewater inflow. Darvill WWW has treated flows as high as 100-120 Ml/d which are almost double its design capacity. High flows reduce the nutrient removal efficiency and 
consequently the legal compliance in terms of the discharge limits set by DWS. This is largely due to the increased organic load and water that comes into the plant. The growth rate of bacteria and available dissolved oxygen in the biological reactor is reduced hence the poor BNR rate. Nitrification and denitrification were also predominantly influenced by temperature as there were observations of low flows but poor $\mathrm{NH}_{3}$ removal during the winter months (June-August) at Darvill WWW with June 2016 having the lowest ammonia removal efficiency (23.2\%). Radical measures should be undertaken to increase aeration capacity and overall plant capacity needs upgrading to improve the BNR process.

\section{ACKNOWLEDGEMENTS}

My sincere acknowledgements go to the following people for their support on the successful completion of this project:

- Umgeni water for giving me the opportunity to utilize their facilities and carry out this project.

- Professor P. Musonge, my supervisor - for being a father and a mentor and always seeing the potential I never thought I had. Thank you for your encouragement and invaluable input in my studies.

- Dr B. Bakare - for co-supervising me and always believing in my abilities. Thank you for stepping in whenever I needed assistance and guidance.

- Mr M. Mnguni - for co-supervising me in the mist of your busy work schedules and always sharing your extensive knowledge in wastewater.

- My family for their unconditional support throughout my studies.

- My Lord, Jesus Christ, who gave me the strength to complete this study.

\section{REFERENCES}

[1] Bashide, M.M., Modelling of Kappala Wastewater Treatment Plant: Evaluation of the influence of storm water to the treatment process, Lund University of Telecommunications, 2015.

[2] Pybus, P.J. et al., Handbook of the Operation of Wastewater Treatment Works, Water Institute of South Africa, Water Research Council and East Rand Water Care Company, 2002.

[3] Tizghadam, M., Dagot C. \& Baudu, M., Wastewater treatment in a hybrid activated sludge baffled reactor. Journal of Hazardous Materials, 154, pp. 550-557, 2008.

[4] Zhirong, H., Houweling, D. \& Dold, P., Biological nutrient removal in municipal wastewater treatment: New directions in sustainability. Journal of Environmental Engineering, 2012. DOI: 10.1061/(ASCE)EE.1943-7870.0000462, 2012.

[5] DWAF, South African Water Quality Guidelines, 2nd ed., 1996. www.dwa.gov.za. Accessed on: 27 Nov. 2018.

[6] Henze, M., van Loosdrecht, M.M.C., Ekama, G.A. \& Brdjanovic, D., Biological Wastewater Treatment, Principles, Modelling and Design, IWA Publishing: London, 2008.

[7] Campos, J.L., Garrido, J.M., Mosquera-Corral, A. \& Méndez, R., Stability of a nitrifying activated sludge reactor. Biochemical Engineering Journal, 35(2007), pp. 87-92, 2007. DOI: 10.1016/j.bej.2007.01.002.

[8] Adonadaga, M., Nutrient removal efficiency of activated sludge plants treating industrial and municipal wastewater in Ghana. Journal of Environment Pollution and Human Health, 2(3), pp. 58-62. DOI: 10.12691/jephh-2-3-1, 2014. 
[9] Falkowski, P.G. \& Godfrey L.V., Electrons, life and the evolution of Earth's oxygen cycle. Phil. Trans. R. Soc. B, 363, pp. 2705-2716, 2008. DOI: 10.1098/rstb.2008.0054.

[10] Wentzel, M.C., Lötter, L.H., Loewenthal, R.E. \& Marais, G.v.R., Metabolic behaviour of Acinetobacter spp. in enhanced biological phosphorus removal: A biochemical model. Water SA, 12(4), pp. 209-224, 1986.

[11] Curtin, K., Duerre, S., Fitzpatrick, B. \& Meyer, P., Biological nutrient removal, Minnesota Pollution Control Agency, 2011. www.pca.state.mn.us/sites/default/files/ wq-wwtp8-21.pdf. Accessed on: 3 Aug. 2019.

[12] Seviour, R.J., Mino, T. \& Onuki, M., The microbiology of biological phosphorus removal in activated sludge systems. Federation of European Microbiological Societies Microbiology Reviews, 27(1), pp. 99-127, 2003.

DOI: 10.1016/S0168-6445(03)00021-4.

[13] Rajasulochana, P. \& Preethy, V., Comparison on efficiency of various techniques in treatment of waste and sewage water: A comprehensive review. Resource-Efficient Technologies, 2, pp. 175-184, 2016. www.sciencedirect.com. Accessed on: 22 Dec. 2018.

[14] Ying Xin Wu, W., Development of a plant-wide steady-state wastewater treatment plant design and analysis program, University of Cape Town, 2015.

[15] Guo, J., Zhang, L., Chen, W., Ma, F., Liu, H. \& Tian, Y., The regulation and control strategies of a sequencing batch reactor for simultaneous nitrification and denitrification at different temperatures. Bioresour. Technol., 133, pp. 59-67, 2013.

[16] Choi, E., Rhu, D., Yun, Z. \& Lee, E., Temperature effects on biological nutrient removal system with weak municipal wastewater. Wat. Sci. Technol., 37(9), pp. 219226, 1998.

[17] Hocaoglu, S.M., Insel, G., Cokgor, E.U. \& Orhon, D., Effect of sludge age on simultaneous nitrification and denitrification in membrane bioreactor. Bioresour. Technol., 102(12), pp. 6665-6672, 2011.

[18] Ydstebo, L., Bilstad, T. \& Barnard J., Experience with biological nutrient removal at low temperatures. Water Environment Research, 72(4), pp. 444-454, 2000. www.jstor.org/stable/25045401. Accessed on: 2 Aug. 2019.

[19] Reddy, Y.V.K., Adamala, S., Levlin, E.K. \& Reddy, K.S., Enhancing nitrogen removal efficiency of domestic wastewater through increased total efficiency in sewage treatment (ITEST) pilot plant in cold climatic regions of Baltic Sea. International Journal of Sustainable Built Environment, 6, pp. 351-358, 2017.

[20] Wang, Y., Peng, Y. \& Stephenson, T., Effect of influent nutrient ratios and hydraulic retention time (HRT) on simultaneous phosphorus and nitrogen removal in a twosludge sequencing batch reactor process. Bioresource Technology, 100(14), pp. 35073512 . 